\title{
Structural and dielectric properties of $\mathrm{Y}_{2}\left(\mathrm{Ba}_{0.5} \mathrm{R}_{0.5}\right)_{2} \mathrm{O}_{7}(\mathrm{R}=\mathrm{W}, \mathrm{Mo})$ ceramics
}

\author{
N.K. Singh ${ }^{\star}$, Pritam Kumar
}

University Department of Physics, V. K. S. University, Ara 802301, India

*Corresponding author. Tel: (+91) 61822 22526; E-mail: singh_nk_phy27@yahoo.com

Received: 24 Jan 2011, Revised: 18 Feb 2011 and Accepted: 08 May 2011

\section{ABSTRACT}

Defect pyrochlore-type $\mathrm{Y}_{2}\left(\mathrm{Ba}_{0.5} \mathrm{R}_{0.5}\right)_{2} \mathrm{O}_{7}(\mathrm{R}=\mathrm{W}$, Mo) oxides ceramics were prepared by using high-temperature solid-state reaction technique. Preliminary studies of X-ray diffraction (XRD) patterns and scanning electron micrographs (SEM) of the compounds at room temperature suggested that compounds have single phase orthorhombic structures and uniform grain distribution throughout the surface of the samples. Detailed studies of dielectric and electrical properties of the materials in a wide range of frequency $(1 \mathrm{kHz}-1 \mathrm{MHz})$ and temperatures $\left(23-344^{\circ} \mathrm{C}\right)$ showed that these properties are strongly temperature and frequency dependent. Variation of dielectric constant $\left(\varepsilon^{\prime}\right)$ and tangent loss $(\tan \delta)$ as a function temperatures showed the abnormal behavior around $132^{\circ} \mathrm{C}$ at $10 \mathrm{kHz}$ and $141^{\circ} \mathrm{C}$ at $30 \mathrm{kHz}$ of $\mathrm{Y}_{2}\left(\mathrm{Ba}_{0.5} \mathrm{~W}_{0.5}\right)_{2} \mathrm{O}_{7}$ and around $293^{\circ} \mathrm{C}$ at $10 \mathrm{kHz}$ and $305^{\circ} \mathrm{C}$ at $30 \mathrm{kHz}$ of $\mathrm{Y}_{2}\left(\mathrm{Ba}_{0.5} \mathrm{Mo}_{0.5}\right)_{2} \mathrm{O}_{7}$ ceramics respectively. Copyright (C) 2011 VBRI press.

Keywords: Pyrochlore; dielectrics; electrical properties; X-ray diffraction; scanning electron micrographs.

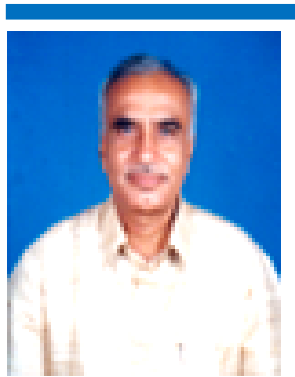

N.K. Singh obtained his M.Sc. degree in physics from Bihar University, Muzaffarpur, India in 1969 and Ph.D. in 1984 from Patna University, Patna. He is Professor and Head, University Department of Physics, V.K.S. University, Ara (India). He is the life member of different academic and Research Societies of India and abroad. He is a member of the Editorial Board of National Journal "ARJP". More than eighteen students have completed their $\mathrm{Ph} . \mathrm{D}$. degrees, under his guidance. $\mathrm{He}$ has published over 61 research papers in peer reviewed journals of the world. He was a U.G.C. Visiting Associate at I.I.T. Kharagpur, India during 2001-2003. In span of 28 years of his research career, he has remained engaged in the preparation of fine ceramics, ferroelectric piezoelectric and non Lead based materials. Presently, he is Principal Investigator of Major Research Project sponsored by DRDO, New Delhi and is engaged in synthesis and characterization of Lead free ferroelectricpiezoelectric systems for sensor applications.

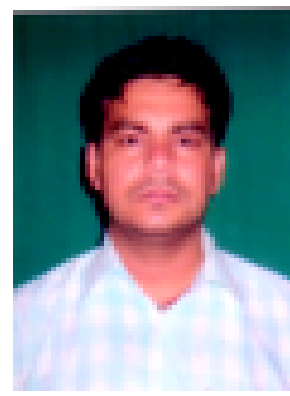

Pritam Kumar obtained M.Sc. degree in physics from T. M. Bhagalpur University, Bhagalpur, India in 2005. He has registered for Ph.D. at T. M. Bhagalpur University on Structural and Dielectric study of some complex perovskite oxides. Presently, he is working as JRF in Major Research Project sponsored by DRDO, New Delhi since 2009 at V.K.S. University, Department of Physics. During his research career, he involved in the preparation of fine ceramics, ferroelectric, piezoelectric and non-lead based materials

\section{Introduction}

Proton conducting ceramics have great technological importance, especially for their applications as sensors, steam electrolysis cells and fuel cells. There are different types of skeleton structures, which facilitate fast ion conduction [1]. Fluorite (F)-type oxides having high potential for oxide-ion conductors can accept various amounts of oxygen vacancy, from which a pyrochlore-type (P) structure can be derived. Although pyrochlore structures are widely used for active and passive electronic devices, such as switching elements, thick-film resistors, and materials for screen printing, they have been recognized only recently as potential candidates for temperature-stable, low-loss, high-permittivity dielectric applications [2-5]. In addition to the above device related promising properties, the system can be synthesized at low temperature $\left(950^{\circ} \mathrm{C}\right)$, which makes them viable as cofired dielectric components. In the resent years, great scientific and technological advances in the ceramics have been made. Ceramics are commonly known for their insulating properties. But in practical, they exhibit a wide range of electrical conductivities, competing metals (highest electronic conductivity) and liquid electrolytes (highest ionic conductivity). Many ceramic materials find applications as capacitor dielectrics, circuit substrates or device packages due to their extremely low electrical conductivities. On the other hand, ceramics find applications in fuel cells, solidstate batteries and gas sensors because of their high ionic conductivities. In some cases high ionic conductivity occurs 
near room temperature, but more commonly the ceramics require high temperatures to achieve useful level of conduction. The physical rigidity of a ceramic makes it useful where a liquid electrolyte would be impractical. Most of the ionic solids are poor ionic conductors. Structure is one of the most importance factors in determining the high ionic conduction in crystalline/polycrystalline solids. Only few ionic solids with open structure exhibit high ionic conductivity at or above room temperature. In the past, several workers [6-8] have developed different skeleton structures (e.g. bcc Im3 phase, carnegieites, pyrochlores, etc.) in order to facilitate fast ion conduction.

The cubic pyrochlore have a general formula $\mathrm{A}_{2} \mathrm{~B}_{2} \mathrm{X}_{6} \mathrm{Y}$. The $\mathrm{B}_{2} \mathrm{X}_{6}$ sub-array forms a rigid skeleton of corner-shared octahedra [9-14]. Octahedra are arranged in a tetrahedral array according to a diamond-type net and a system of open channels is observed parallel to the (110) direction and to that equivalent to cubic symmetry. In a normal pyrochlore, the channel contains an $\mathrm{A}_{2} \mathrm{Y}^{\prime}$ array. The chemical bond between the rigid framework $\left(\mathrm{BX}_{3}\right)_{\mathrm{n}}$ and the loose array $\left(\mathrm{A}_{2} \mathrm{Y}^{\prime}\right)_{\mathrm{n}}$ may be more or less weak. Because of the weak interaction, the $\mathrm{A}$ and $\mathrm{Y}$ atoms may be partly or completely missing which gives rise to 'defect' pyrochlores [15]. 'Defect' pyrochlores have a $\mathrm{B}_{2} \mathrm{X}_{6}$ network similar to regular pyrochlores but with vacancies introduced in the $\mathrm{A}_{2} \mathrm{Y}$ array. This structural disorder makes fast ion conduction possible. These compounds have a tendency to absorb moisture from the atmosphere at room temperature $\left(\approx 23^{\circ} \mathrm{C}\right)$, i.e. the room temperature phases of the compounds are hydrated [1]. The absorbed water can be removed by heating the compounds. The ionic properties of these compounds are very much influenced by absorbed water. Though studies of structural, thermal and ionic properties of some members of defect pyrochlore-type $\mathrm{AB}^{\prime} \mathrm{WO}_{6}$ (where $\mathrm{A}=$ alkali ions, $\mathrm{B}^{\prime}=\mathrm{Nb}$, Ta) family have already been reported $[15,16]$, no information is available on the dielectric and related properties of these compounds. In view of the importance of the materials and unavailability of the dielectric data, we carried out systematic and extensive studies on structural, dielectric and electrical conducting properties of $\mathrm{Y}_{2}\left(\mathrm{Ba}_{0.5} \mathrm{~W}_{0.5}\right)_{2} \mathrm{O}_{7} \quad(\mathrm{YBW})$ and $\mathrm{Y}_{2}\left(\mathrm{Ba}_{0.5} \mathrm{Mo}_{0.5}\right)_{2} \mathrm{O}_{7} \quad(\mathrm{YBM})$ ceramics.

\section{Experimental}

\section{Materials and Methods}

Polycrystalline samples of Yttrium barium tungstate, $\mathrm{Y}_{2}\left(\mathrm{Ba}_{0.5} \mathrm{~W}_{0.5}\right)_{2} \mathrm{O}_{7}$, (YBW) and Yttrium barium molybdate, $\mathrm{Y}_{2}\left(\mathrm{Ba}_{0.5} \mathrm{Mo}_{0.5}\right)_{2} \mathrm{O}_{7}$, (YBM) oxides were prepared by employing a high-temperature solid-state reaction technique using high purity carbonate and oxides: $\mathrm{BaCO}_{3}$ (99\% Burgoyne Buirbridger, India), $\mathrm{Y}_{2} \mathrm{O}_{3}(99 \% \mathrm{M} / \mathrm{S}$ Indian Rare Earth Ltd.), $\mathrm{WO}_{3}(99 \% \mathrm{M} / \mathrm{SJ}$ ohn Baker Inc., USA) and $\mathrm{MoO}_{3}, \mathrm{M} / \mathrm{S}$ Loba Chemie Pvt. Ltd., India) in required stoichiometry. The mixture of ingredients of the YBW and YBM were calcined in alumina crucible at $1100^{\circ} \mathrm{C}$ for $\sim 12$ $\mathrm{h}$ in air atmosphere. The process of grinding and calcination was repeated twice, for the formation of the compounds. The final calcinations were done at 1170 and $1150^{\circ} \mathrm{C}$ for tungstate and molybdate compounds, respectively. The homogenous calcined powders of YBW and YBM mixed with binder (polyvinyl alcohol (PVA)) and compacted into cylindrical discs (pellets) of diameter $\sim 10 \mathrm{~mm}$ and thickness $1.86 \mathrm{~mm}$ to $2.01 \mathrm{~mm}$. The pellets of $\mathrm{YBW}$ and YBM were sintered at $1220^{\circ} \mathrm{C}$ for $10 \mathrm{~h}$. The formation of the desired compound was checked by a preliminary X-ray structural study by X-ray diffractometer on calcined powder of YBW and YBM in a wide range of Bragg angles $2 \theta\left(20^{\circ}\right.$ $\leq 2 \theta \leq 80^{\circ}$ ) at room temperature using a Philip PW $1977 \mathrm{X}$ ray diffractometer with $\mathrm{Cuk}_{\alpha}$ radiation $(\lambda=0.15418 \mathrm{~nm}$ with a scanning rate of $\sim 2^{\circ} \mathrm{min}^{-1}$. The morphology of the surface was examined by SEM (JOEL-JSM, model: 5800). The flat polished surfaces of sintered pellets were electroded/ painted with a high- purity air- dried silver paste, and then dried (fired on) at $150^{\circ} \mathrm{C}$ for $\sim 2 \mathrm{~h}$ before taking any dielectric/electrical measurements. From the measurement, we have obtained capacitance (C) and tangent loss $(\tan \delta)$ of the samples as a function of frequency at room temperature and temperatures $\left(23-344^{\circ} \mathrm{C}\right)$ at different frequencies (10 and $30 \mathrm{kHz}$ ) from HIOKI 3552 LCR Hi-tester and laboratory- made three-terminal sample holder. By using $(\mathrm{C})$ and $(\tan \delta)$, we have computed dielectric constant $\left(\varepsilon^{\prime}\right)$ and conductivity $(\sigma)$ as follows:

$$
\begin{aligned}
& \varepsilon^{\prime}=\varepsilon_{0}\left(C / C_{0}\right) \\
& \sigma=\omega \varepsilon_{0} \varepsilon^{\prime \prime}
\end{aligned}
$$

where $\varepsilon_{0}$ is the dielectric permittivity in air, $\mathrm{C} / \mathrm{C}_{0}$ the ratio of capacitance measured with dielectric and without dielectric, $\omega$ the angular frequency and $\varepsilon^{\prime \prime}=\tan \delta \varepsilon^{\prime}$.

\section{Results and discussion}

\section{Microstructure analysis}

The sharp and single diffraction peaks in room temperature XRD pattern of all the compounds (YBW and YBM) are shown in Fig. 1(a, b). All the peaks were indexed and the cell parameters were determined in different crystal systems using a standard computer program POWDMULT [17]. Finally, a unit cell of orthorhombic crystal system was selected for which $\sum \Delta \mathrm{d}$ $=\left(\mathrm{d}_{\mathrm{obs}}-\mathrm{d}_{\mathrm{cal}}\right)$ was found to be minimum (standard deviation is $0.004 \AA$ Á). A good agreement between the observed and calculated d-values shows the correctness of the selection of crystal system and unit cell parameters. The least-squares refined parameters for YBW and YBM compounds are given in Table 1(a, b). The linear particle size $\left(\mathrm{P}_{\mathrm{hkl}}\right)$ of both the samples was calculated from some strong and medium intensity peaks using Scherrer's equation [18] $\mathrm{P}=0.89 \lambda /\left(\beta_{1 / 2} \operatorname{Cos} \theta_{\mathrm{hkl}}\right)$, where $\lambda$ is the wavelength of $X$-ray radiation, $\beta_{1 / 2}=$ half peak width of the diffracted peak and $\theta_{\mathrm{hkl}}$ the angle of diffraction. The scanning electron micrograph of the sample was recorded by FEI Quanta 200 equipment to check proper compactness of the sample. The surface micrographs of the YBW and YBM compounds at same magnification are shown in Fig. 2(a, b). The nature of the micrographs exhibits the polycrystalline texture of the material having highly distinctive and compact rectangular/cubical grain distributions (with less voids). The grain size of YBW and YBM was found to be in the range of $0.1-1.7$ and $0.2-2.8 \mu \mathrm{m}$, respectively. 

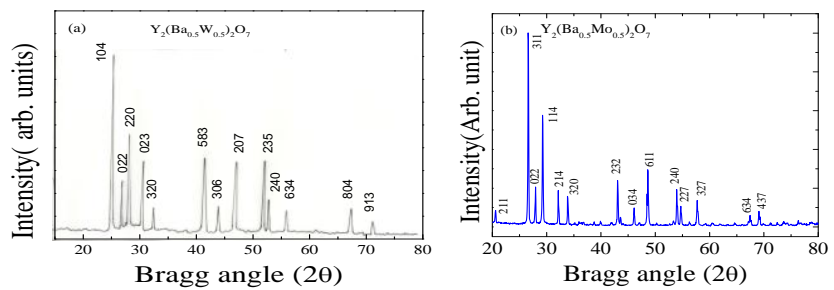

Fig. 1. Room temperature $X R D$ patterns of (a) $\mathrm{Y}_{2}\left(\mathrm{Ba}_{0.5} \mathrm{~W}_{0.5}\right)_{2} \mathrm{O}_{7}$ (YBW) and (b) $\mathrm{Y}_{2}\left(\mathrm{Ba}_{0.5} \mathrm{Mo}_{0.5}\right)_{2} \mathrm{O}_{7}(\mathrm{YBM})$ samples, respectively.

Table 1. (a, b) Comparison of some observed (obs) and calculated (cal) $\mathrm{d}$ values (in $\mathrm{nm}$ ) of some reflections of $\mathrm{Y}_{2}\left(\mathrm{Ba}_{0.5} \mathrm{~W}_{0.5}\right)_{2} \mathrm{O}_{7}(\mathrm{YBW})$ and $\mathrm{Y}_{2}\left(\mathrm{Ba}_{0.5} \mathrm{Mo}_{0.5}\right)_{2} \mathrm{O}_{7}(\mathrm{YBM})$ ceramics at room temperature. The estimated error in $\mathrm{d}$ is $\pm 0.00010 \mathrm{~nm}$.

Table 1(a)

\begin{tabular}{cccccc}
\hline $\mathrm{h}$ & $\mathrm{k}$ & $\mathrm{l}$ & $\mathrm{d}_{\mathrm{obs}}$ & $\mathrm{d}_{\text {cal }}$ & $\mathrm{I} / \mathrm{I}_{\mathrm{o}}$ \\
\hline 1 & 0 & 4 & 3.314 & 3.312 & 100 \\
0 & 2 & 2 & 3.1372 & 3.1394 & 35 \\
2 & 2 & 0 & 3.0279 & 3.0273 & 60 \\
0 & 2 & 3 & 2.7968 & 2.8001 & 45 \\
3 & 2 & 0 & 2.6330 & 2.6283 & 14 \\
5 & 8 & 3 & 2.1081 & 2.1073 & 47 \\
3 & 0 & 6 & 1.9935 & 1.9922 & 20 \\
2 & 0 & 7 & 1.8770 & 1.8760 & 45 \\
2 & 3 & 5 & 1.7142 & 1.7143 & 45 \\
2 & 4 & 0 & 1.6879 & 1.6881 & 25 \\
6 & 3 & 4 & 1.3849 & 1.3848 & 12 \\
8 & 0 & 4 & 1.3610 & 1.3612 & 20 \\
9 & 1 & 3 & 1.2452 & 1.2456 & 10 \\
\hline
\end{tabular}

Table 1(b)

\begin{tabular}{cccccc}
\hline $\mathrm{h}$ & $\mathrm{k}$ & $\mathrm{l}$ & $\mathrm{d}_{\mathrm{obs}}$ & $\mathrm{d}_{\text {cal }}$ & $\mathrm{I} / \mathrm{I}_{\mathrm{o}}$ \\
\hline 2 & 1 & 1 & 4.3115 & 4.3151 & 8 \\
3 & 1 & 1 & 3.3387 & 3.100 & 100 \\
0 & 2 & 2 & 3.1922 & 3.1748 & 20 \\
1 & 1 & 4 & 3.0532 & 3.0453 & 56 \\
2 & 1 & 4 & 2.7789 & 2.7787 & 20 \\
3 & 2 & 0 & 2.6367 & 2.6350 & 14 \\
2 & 3 & 2 & 2.1011 & 2.0995 & 23 \\
0 & 3 & 4 & 1.9689 & 1.9664 & 8 \\
6 & 1 & 1 & 1.8733 & 1.8734 & 30 \\
2 & 4 & 0 & 1.6995 & 1.7028 & 18 \\
2 & 2 & 7 & 1.6780 & 1.6771 & 11 \\
3 & 2 & 7 & 1.5977 & 1.5979 & 13 \\
6 & 3 & 4 & 1.3885 & 1.3884 & 6 \\
4 & 3 & 7 & 1.3593 & 1.3596 & 8 \\
\hline
\end{tabular}

\section{Dielectric relaxation}

Fig. 3 and Fig. 4 shows the frequency $(1 \mathrm{kHz}-1 \mathrm{MHz})$ dependence of relative dielectric constant $\left(\varepsilon^{\prime}\right)$ and tangent loss $(\tan \delta)$ at room temperature $\left(\sim 23^{\circ} \mathrm{C}\right)$ of $\mathrm{YBW}$ and $\mathrm{YBM}$ ceramics respectively. It has been observed that the values of the dielectric constant $\left(\varepsilon^{\prime}\right)$ of the above compounds decrease with increasing frequency indicating a normal behavior of dielectrics/ferroelectrics. The nature of dielectric constant $\left(\varepsilon^{\prime}\right)$ related to free dipoles oscillating in an alternating field may be described in the following way.
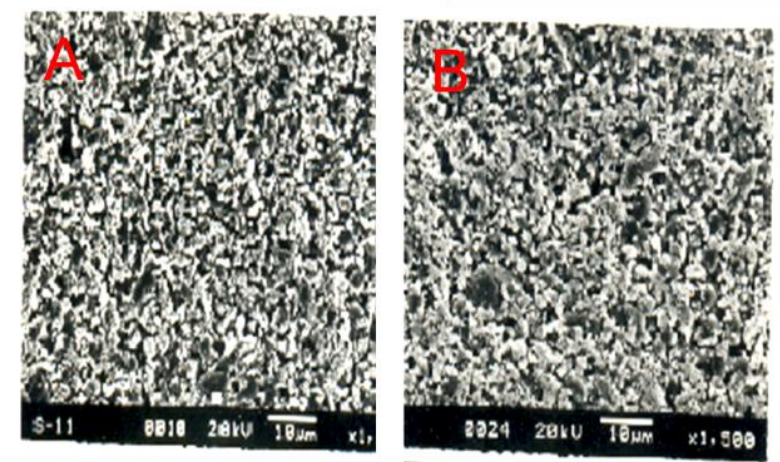

Fig. 2. The SEM micrograph of powder specimens of (a) $\mathrm{Y}_{2}\left(\mathrm{Ba}_{0.5} \mathrm{~W}_{0.5}\right)_{2} \mathrm{O}_{7}(\mathrm{YBW})$ and (b) $\mathrm{Y}_{2}\left(\mathrm{Ba}_{0.5} \mathrm{Mo}_{0.5}\right)_{2} \mathrm{O}_{7}(\mathrm{YBM})$ compounds.

At very low frequencies $(\omega<<1 / \tau, \tau$ is the relaxation time), dipoles follow the field and $\varepsilon^{\prime} \approx \varepsilon_{\mathrm{s}}$ (value of the dielectric constant at quasi-static field). As the frequency increases (with $\omega<1 / \tau$ ), dipoles begin to lag behind the field and $\varepsilon^{\prime}$ slightly decreases. When frequency reaches the characteristic frequency $(\omega=1 / \tau)$, the dielectric constant drops (relaxation process). At very high frequencies $(\omega>>1 / \tau)$, dipoles can no longer follow the field and $\varepsilon^{\prime} \approx \varepsilon_{\infty}$ (high-frequency value of $\varepsilon^{\prime}$ ). The YBM compound has the highest dielectric constant as compare to YBW compounds. This is due to the presence of all the different types of polarization polarizations (viz. electronic, ionic, interfacial / surface polarization) in the compound at low temperature and frequency. At higher frequency (i.e.> $50 \mathrm{kHz}$ ) the contribution from interfacial, dipolar and atomic / ionic is zero and hence, we have only an electronic contribution, as a result we get a lower value of the dielectric constant $\left(\varepsilon^{\prime}\right)$. In the case of $\tan \delta$, it is very similar nature like that of dielectric constant. This type of variation was also observed in some of the ceramics of this family [19-23].

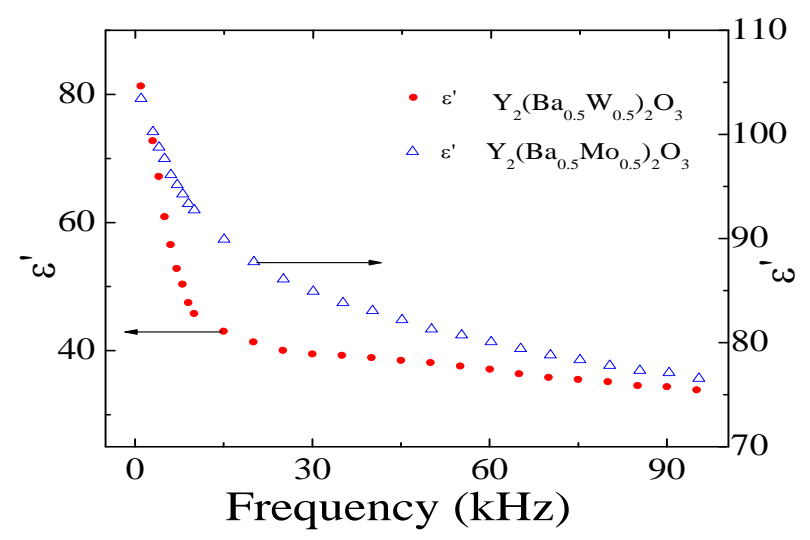

Fig. 3. Variation of relative dielectric constant $\left(\varepsilon^{\prime}\right)$ of $\mathrm{Y}_{2}\left(\mathrm{Ba}_{0.5} \mathrm{~W}_{0.5}\right)_{2} \mathrm{O}_{7}$ and $\mathrm{Y}_{2}\left(\mathrm{Ba}_{0.5} \mathrm{Mo}_{0.5}\right)_{2} \mathrm{O}_{7}$ with frequency at room temperature. 


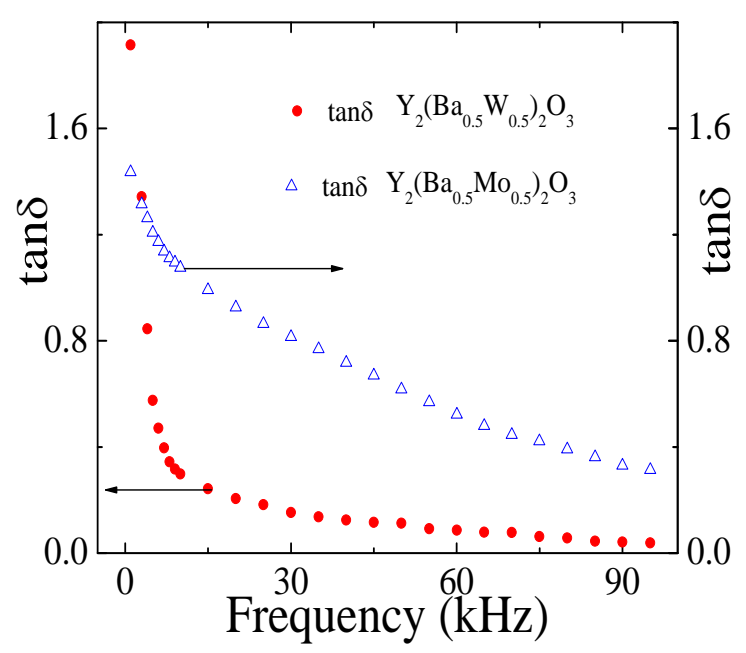

Fig. 4 Variation of variation of tangent loss $(\tan \delta)$ of $\mathrm{Y}_{2}\left(\mathrm{Ba}_{0.5} \mathrm{~W}_{0.5}\right)_{2} \mathrm{O}_{7}$ and $\mathrm{Y}_{2}\left(\mathrm{Ba}_{0.5} \mathrm{Mo}_{0.5}\right)_{2} \mathrm{O}_{7}$ with frequency at room temperature.

The variation of dielectric constant $\left(\varepsilon^{\prime}\right)$ and tangent loss $(\tan \delta)$ as a function of temperature $\left(23-344^{\circ} \mathrm{C}\right)$ at $10 \mathrm{kHz}$ and $30 \mathrm{kHz}$ frequencies of YBW and YBM ceramics is shown in Fig. 5 and Fig. 6. The value of dielectric constant $\left(\varepsilon^{\prime}\right)$ increases gradually to a maximum value $\left(\varepsilon_{\mathrm{m}}^{\prime}\right)$ with increase in temperature and then decreases smoothly indicating a phase transition. The abnormal behavior around $132^{\circ} \mathrm{C}$ at $10 \mathrm{kHz}$ and $141^{\circ} \mathrm{C}$ at $30 \mathrm{kHz}$ of $\mathrm{YBW}$ and around $293^{\circ} \mathrm{C}$ at $10 \mathrm{kHz}$ and $305^{\circ} \mathrm{C}$ at $30 \mathrm{kHz}$ of $\mathrm{YBM}$ ceramics respectively [24]. The maximum of dielectric constant $\left(\varepsilon_{\mathrm{m}}^{\prime}\right)$ and the corresponding temperature maximum $\left(\mathrm{T}_{\mathrm{m}}\right)$ depend upon the measurement frequency for YBW and YBM ceramics. The magnitude of dielectric constant decreases with increase in frequency and the maximum shifts to higher temperature [25]. This indicates that the dielectric polarization is of relaxation type in nature in YBW and YBM ceramics. The dielectric constant of YBM is higher than YBW ceramics. At room temperature, the tan $\delta$ of YBM was in the range of 0.80 to 1.07 and 0.15 to0.29 for YBW ceramics. With increasing measured frequency the peak position of tangent loss $(\tan \delta)$ shift the higher temperature. A decrease in the peak value of loss tangent $(\tan \delta)$ with increasing frequency is observed as well.

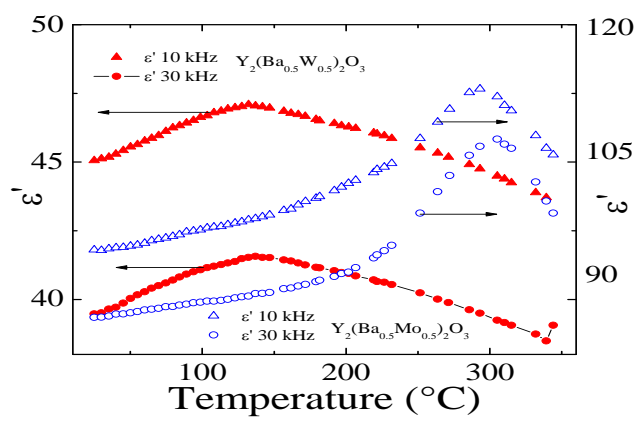

Fig. 5. Variation of relative dielectric constant $\left(\varepsilon^{\prime}\right)$ of $\mathrm{Y}_{2}\left(\mathrm{Ba}_{0.5} \mathrm{~W}_{0.5}\right)_{2} \mathrm{O}_{7}$ and $\mathrm{Y}_{2}\left(\mathrm{Ba}_{0.5} \mathrm{Mo}_{0.5}\right)_{2} \mathrm{O}_{7}$ with temperature at frequencies 10 and $30 \mathrm{kHz}$.

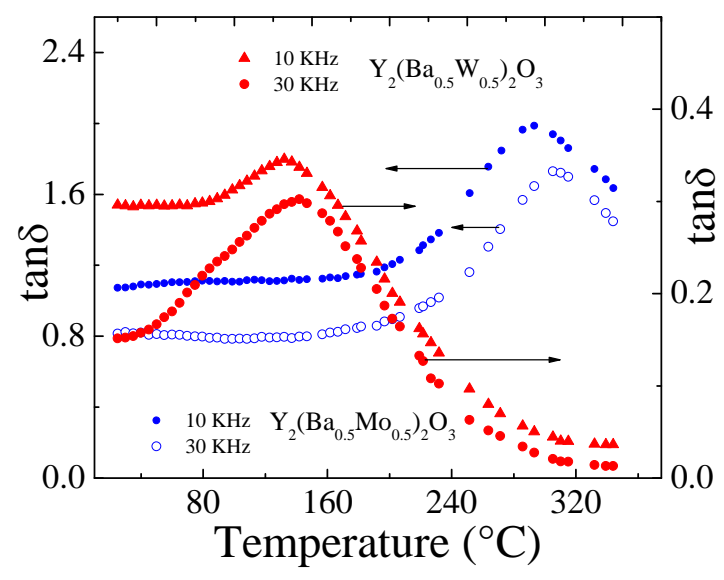

Fig. 6 Variation of tangent loss $(\tan \delta)$ of $\mathrm{Y}_{2}\left(\mathrm{Ba}_{0.5} \mathrm{~W}_{0.5}\right)_{2} \mathrm{O}_{7}$ and $\mathrm{Y}_{2}\left(\mathrm{Ba}_{0.5} \mathrm{Mo}_{0.5}\right)_{2} \mathrm{O}_{7}$ with temperature at frequencies 10 and $30 \mathrm{kHz}$.

In Table 2, the refined lattice parameters and some dielectric data of the YBW and YBM ceramics have been compared.

Table 2. Comparison of lattice parameters, a, b, and c $(\mathrm{nm})$, volume $\left(\mathrm{nm}^{3}\right)$ and other related dielectric data $\mathrm{Y}_{2}\left(\mathrm{Ba}_{0.5} \mathrm{~W}_{0.5}\right)_{2} \mathrm{O}_{7} \quad(\mathrm{YBW})$ and $\mathrm{Y}_{2}\left(\mathrm{Ba}_{0.5} \mathrm{Mo}_{0.5}\right)_{2} \mathrm{O}_{7}(\mathrm{YBM})$ ceramics.

\begin{tabular}{lll}
\hline Parameters & $\mathrm{Y}_{2}\left(\mathrm{Ba}_{0.5} \mathrm{Mo}_{0.5}\right)_{2} \mathrm{O}_{7}$ & $\mathrm{Y}_{2}\left(\mathrm{Ba}_{0.5} \mathrm{~W}_{0.5}\right)_{2} \mathrm{O}_{7}$ \\
\hline $\mathrm{a}$ & $1.1768(4)$ & $1.18434(4)$ \\
$\mathrm{b}$ & $0.7115(7)$ & $0.70449(7)$ \\
$\mathrm{c}$ & $1.4060(9)$ & $1.38454(9)$ \\
$\varepsilon_{\mathrm{RT}}^{\prime}$ at $10 \mathrm{kHz}$ & 93 & 45 \\
$\varepsilon_{\mathrm{RT}}^{\prime}$ at $30 \mathrm{kHz}$ & 95 & 39 \\
$\tan \delta_{\mathrm{RT}}$ at $10 \mathrm{kHz}$ & 1.07 & 0.29 \\
$\tan \delta_{\mathrm{RT}}$ at $30 \mathrm{kHz}$ & 0.81 & 0.15 \\
$\varepsilon_{\max }^{\prime}$ at $10 \mathrm{kHz}$ & 112 & 48 \\
$\varepsilon_{\max }^{\prime}$ at $30 \mathrm{kHz}$ & 1106 & 42 \\
$\tan \delta_{\max }$ at $10 \mathrm{kHz}$ & 1.98 & 0.34 \\
$\tan \delta_{\max }$ at $30 \mathrm{kHz}$ & 1.73 & 0.30 \\
& & \\
\hline
\end{tabular}

Fig. 7 shows the variation of ac conductivity $\left(\ln \sigma_{a c}\right)$ of YBW and YBM ceramics with inverse of absolute temperature $(1 / \mathrm{T})$ of the compound at $10 \mathrm{kHz}$. The temperature dependence of ac electrical conductivity $\left(\ln \sigma_{\mathrm{ac}}\right)$ and activation energy $\left(E_{a}\right)$ of the YBW and YBM compounds were calculated from the impedance data collected with an LCR meter and using the formula [21, 26]

$\sigma=\omega \varepsilon_{0} \varepsilon^{\prime} \tan \delta$

Arrhenius law:

$\sigma_{\mathrm{ac}}=\sigma_{0} \exp \left(-\mathrm{E}_{\mathrm{a}} / \mathrm{k}_{\mathrm{B}} \mathrm{T}\right)$

where $\omega$ is the angular frequency, $\varepsilon_{0}$ is the vacuum permittivity and $\mathrm{k}_{\mathrm{B}}$ is the Boltzmann constant.

The value of the activation energy $E_{a}$ has been calculated from the slope of the graph in high-temperature 
region $\left(>305^{\circ} \mathrm{C}\right)$ and was found to be $0.16 \mathrm{eV}$ for $\mathrm{YBW}$ compound and $0.11 \mathrm{eV}$ for YBM compound at $10 \mathrm{kHz}$. The low values of activation energy support the superionic nature of the compounds in the high-temperature region. In both the compounds the ac conductivity $\left(\ln \sigma_{\mathrm{ac}}\right)$ increases sharply with rise in temperature. This increased conductivity is due to the movement of thermal ions (generally hopping motion of ions) from one preferable site to other and also due to the creation of vacancies or defects at higher temperatures. The calculated value of activation energy required to activate the motion of these ions and vacancies.

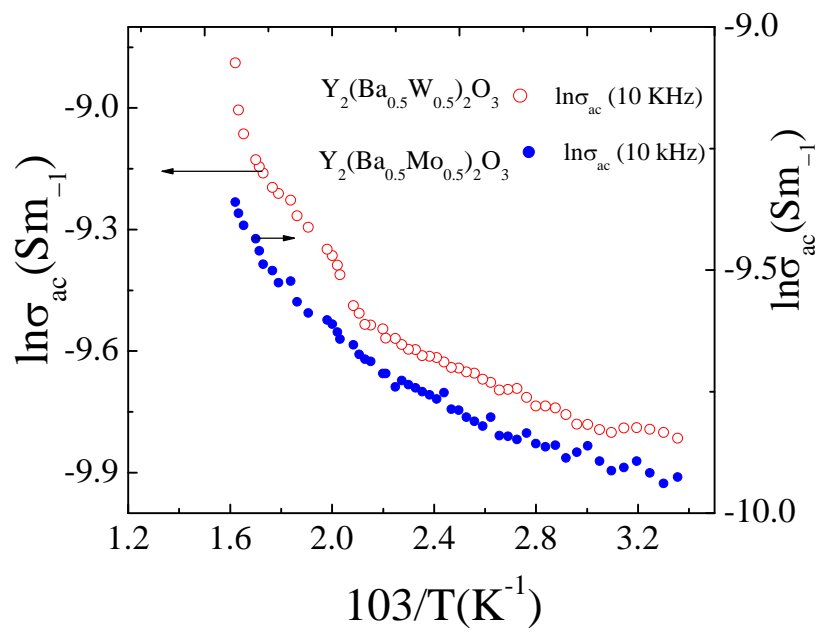

Fig. 7. Variation of ac conductivity $\left(\ln \sigma_{\mathrm{ac}}\right)$ of $\mathrm{Y}_{2}\left(\mathrm{Ba}_{0.5} \mathrm{~W}_{0.5}\right)_{2} \mathrm{O}_{7}$ and $\mathrm{Y}_{2}\left(\mathrm{Ba}_{0.5} \mathrm{Mo}_{0.5}\right)_{2} \mathrm{O}_{7}$ with inverse of absolute temperature $(1 / \mathrm{T})$ at $10 \mathrm{kHz}$.

\section{Conclusion}

Finally, it can be concluded that defect pyrochlore-type $\mathrm{Y}_{2}\left(\mathrm{Ba}_{0.5} \mathrm{R}_{0.5}\right)_{2} \mathrm{O}_{7} \quad(\mathrm{R}=\mathrm{W}, \mathrm{Mo})$ ceramics have an orthorhombic crystal structure at room temperature $\left(\sim 23^{\circ} \mathrm{C}\right)$. The microstructure of the ceramics was examined by the scanning electron micrograph (SEM), and shows the polycrystalline nature of the samples with different grain sizes, which are inhomogeneously distributed through the sample surface. Detailed studies of dielectric and electrical properties of the materials in a wide range of frequency ( 1 $\mathrm{kHz}-1 \mathrm{MHz})$ and temperatures $\left(23-344^{\circ} \mathrm{C}\right)$ showed that these properties are strongly temperature and frequency dependent. The value of the activation energy $E_{a}$ was found to be $0.16 \mathrm{eV}$ for YBW compound and $0.11 \mathrm{eV}$ for YBM compound at $10 \mathrm{kHz}$. The low values of activation energy support the superionic nature of the compounds in the hightemperature region.
4. Lacorre, P.; Goutenoire, F.; Bohnke, O.; Petoux, R.; Laligant, Y. Nature 2000, 404,856 .

DOI: $10.1038 / 35009069$

5. Cann, D.P.; Randall, C.A.; Shrout, T.R. Solid State Commun. 1996, 7, 529. DOI: $10.1016 / 0038-1098(96) 00012-9$

6. Singer, J.; Fielder, W.L.; Kautz, H.E.; Fordyce, J.S. Electro-Chem. Soc. 1976, 123, 614. DOI: org/10.1149/1.2132895

7. Kuwabara, K.; Takahasi, T. J. Solid State Chem. 1976, 19, 147. DOI: $10.1016 / 0022-4596(76) 90162-6$

8. Trichet, L.; Rouxel, J. Nater. Res. Bull. 1977, 12, 345. DOI: $10.1016 / 0025-5408(77) 90050-2$

9. Mari, C.M.; Bonino, F.; Catti, M.; Pasinetti, R.; Pizzini, S. Solid State Ionics-Diffus. React. 1986, 18/19, 1013. DOI: $10.1016 / 0167-2738(86) 90301-2$

10. Tiwari, A.; Prabaharan, M.; Pandey, R.R.; Li, S. J Inorg Organomet Polym 2010, 20, 380.

DOI: $10.1007 / \mathrm{s} 10904-010-9354-9$

11. Singh, N. K.; Kumar, P.; Kumar, H.; Rai, R. Adv. Mat. Lett. 2010, 1, 79. DOI: $10.5185 /$ amlett. 2010.3102

12. Singh, N. K.; Kumar, P.; Roy, O. P.; Rai, R. J. Alloys and Compounds 2010, 507, 542 .

DOI: $\underline{10.1016 / \text { j.jallcom.2010.08.015 }}$

13. Tiwari, A.; Li, S. Polymer Journal 2009, 41, 726. DOI: $10.1295 /$ polymj.PJ2009059

14. Rai R. Adv. Mat. Lett. 2010, 1,55. DOI: $10.5185 /$ amlett.2010.3101

15. Babel, D.; Pausewang, G.; Viebahn, W. Naturforsch, Z. 1967, 22b, 1219.

16. Michel, C.; Groult, D.; Raveau, B. J. Inorg. Nucl. Chem. 1975, 37, 247. DOI: $10.1016 / 0022-1902(75) 80158-8$

17. Wul E, PowdMult, An interactive powder diffraction data interpretation and index program, version 2.1, school of Physical science, Flinders University of South Australia, Bedford Park, S.A. 5042, Australia.

18. Scherrer, P. Gottin Nachricht 1918, 2, 98.

19. Singh, N. K.; Choudhary, R.N.P.; Banarji, B. Physica B 2008, 403, 1673. DOI: 10.1016 j. physb2007.09.083

20. Kumar, P.; Singh, B.P.; Sinha, T.P.; Singh, N.K. Physica B 2011, 406 , 139.

DOI: $10.1016 /$ j.phyb.2010.09.019

21. Singh, N.K.; Sharma, S.; Choudhary, R.N.P. Indian J. Phys. 2000, 74B, 63.

22. Kumar, P.; Singh, B.P.; Sinha, T.P.; Singh, N.K. Adv. Mat. Lett. 2011, 2(1), 76. DOI: $10.5185 /$ amlett. 2010.11176

23. Singh, N. K.; Kumar, P.; Rai, R.; Adv. Mat. Lett. 2011, In press.

24. Cheng, Z.X.; Wang, X.L.; Alvarez, G.; Dou, S.X.; Zhang, S.J.; Shrout, T.R. J. Appl. Phys. 2009, 105, 07D902. DOI: $10.1063 / 1.3055266$

25. Badapanda, T.; Rout, S. K.; Panigrahi, S.; Sinha, T.P. Current Applied Physics 2009, 9, 727.

DOI: $10.1016 /$ j.cap.2008.06.014

26. Qurevich, V. M.; Electric Conductivity of Ferroelectrics Moskva 1969.

\section{Acknowledgement}

The authors also acknowledge Prof. R.N.P. Choudhary, IIT Kharagpur, India for some help in experimental work and suggestion.

\section{Reference}

1. Goodenough, J.B.; Hong, H .Y-P.; Kafalas, J.A. Mat. Res. Bull. 1986, 11, 203.

2. Chadwick, A.V. Nature 2000, 408, 925.

DOI: $\underline{10.1038 / 35050201}$

3. Goodenough, J.B. Nature 2000, 404, 821.

DOI: $10.1038 / 35009177$ 


\section{AdVANCEd MATERIALS Letters}

\section{Publish your article in this journal}

ADVANCED MATERIALS Letters is an international journal published quarterly. The journal is intended to provide top-quality peer-reviewed research papers in the fascinating field of materials science particularly in the area of structure, synthesis and processing, characterization, advanced-state properties, and applications of materials. All articles are indexed on various databases including DOAJ and are available for download for free. The manuscript management system is completely electronic and has fast and fair peer-review process. The journal includes review articles, research articles, notes, letter to editor and short communications. 